\title{
MITIGATION OF NOISE USING CONCRETE BARRIER
}

\author{
Naveen G.M ${ }^{\mathbf{1}}$, Ichitha M. K ${ }^{\mathbf{2}}$, Ravi Kiran L ${ }^{3}$, Ayushi G Jain ${ }^{4}$ \\ ${ }^{1}$ Asst. Professor, Department of Civil Engineering, Government Engineering College, Karnataka, India \\ ${ }^{2}$ Asst. Professor, Department of Civil Engineering, Vidyavardhaka College of Engineering, Karnataka, India \\ ${ }^{3}$ Asst. Professor, Department of Civil Engineering, Sambhram Institute of Technology, Karnataka, India \\ ${ }^{4}$ Project Associate, Department of Civil Engineering, Vidya Vikas Institute of Engineering and Technology, \\ Karnataka, India
}

\begin{abstract}
Noise is a displeasing effect on human health that disrupts the activity of daily life. Noise pollution can cause annoyance and aggression, hypertension, high stress levels, tinnitus, hearing loss, sleep disturbances and other harmful effects. One of the major sources of noise is traffic density. Hence an attempt has been made to reduce noise level by studying the traffic density and noise range produced at different roads of Mysore city. The roads selected were based on sensitive zones such as hospitals, schools, colleges and court of Mysore city. The maximum noise produced due to traffic was noted and suggestions were given to reduce noise level. The concrete barrier with certain alterations in concrete mix can be a solution to achieve good acoustic performance. In this context, an experimental study was conducted to obtain data on performance of concrete barrier by using buffer rubber in concrete mix. Concrete mix was prepared in 1:1.5:3 proportion by using cement, sand and coarse aggregate with water/cement ratio of 0.55 . The fine aggregate was replaced by varying percentage of rubber. The concrete panels were then subjected to strength and acoustic tests to ensure its effectiveness. The fine aggregate up to 35\% replacement with compressive strength $19.6 \mathrm{~N} / \mathrm{mm}^{2}$ achieved sound absorption capacity up to $27.5 \mathrm{~dB}$.
\end{abstract}

Keywords: Buffer rubber, Compressive strength, Noise, Mitigation

\section{INTRODUCTION}

The Noise, unwanted sound has penetrated almost every aspect of modern life. The increased level of noise pollution affects the welfare of human life, animals, plants, structures and finally affects their existence, which are caused due to urbanization, mechanized means of transport and new devices of recreation and entertainment. It is potentially a serious signal \& grave threat to the human health and environment.

Noise is transmitted through various ways i.e. through air, by vibrations of structural members and through structural members. When sound is transmitted from the source or the origin to the adjoining room/area, reduction in sound intensity takes place, this is known as transmission loss. It is numerically equal to the loss in the intensity of sound expressed in decibels.

Nowadays noise level has increased due to increase in traffic density. Hence, sound barriers are used to reduce noise along highways. Sound barriers can be built on new as well as existing roads to reduce noise level by 10 to 15 decibels, which is cutting the sound in half. Usually there will be one decibel reduction for every two feet vertical height of barrier added. Sound barrier can be constructed out of concrete, stucco, masonry, wood, and metal. While designing a sound barrier one must consider the most effective way to reduce noise with its location. A sound barrier will work only if the resident behind it is in the shadow zone. In this research work an attempt has been made to use sound barrier of concrete material with replacement of fine aggregate by buffering rubber obtained from tires.

\section{METHODOLOGY}

\subsection{Traffic Survey}

Mysore, the administrative center of Mysore District is second largest city of Karnataka and is situated in the southern part of the state at $763 \mathrm{~m}$ above sea level at latitude of $12^{\circ} 18^{\prime} \mathrm{N}$ and longitude of $76^{\circ} 42^{\prime} \mathrm{E}$. The city is located at a distance of about $135 \mathrm{~km}$ from Bangalore, the capital of the state. Since it is heritage city tourist activity is more which is one of the contributing factors for high traffic density.

In this research, primarily traffic survey has been conducted to check the traffic density and noise level using Sound Level Meter in sensitive zones viz., hospitals, court, schools and colleges at different time duration near important places to know the effect of traffic pollution.

The SOUND LEVEL METER instrument was used to measure noise absorption capacity of the concrete barriers in the laboratory. Sound level meter is an instrument, which indicates, sound pressure levels (SPL) in the audible range. Its purpose is to provide a result, which can give a reasonably good indication of human perception of the measured sound.

It measures, the root mean square sound pressure with the aid of a microphone that converts the signal to an equal electrical signal. The signal is passed to weighting network, which provides a conversion and gives the sound pressure level in $\mathrm{dB}$. Sound Level Meter is as shown in Fig-1. 
The first study location is the JSS hospital road in Agarahara nearly $2 \mathrm{~km}$ away from the city bus stand (main city). The second study location is at Sadvidya PU College in Narayanshastri road and the third study location is at District court road. The monitored values obtained are compared with Standard values as per "The Noise Pollution (Regulation and Control) Rules, 2000".

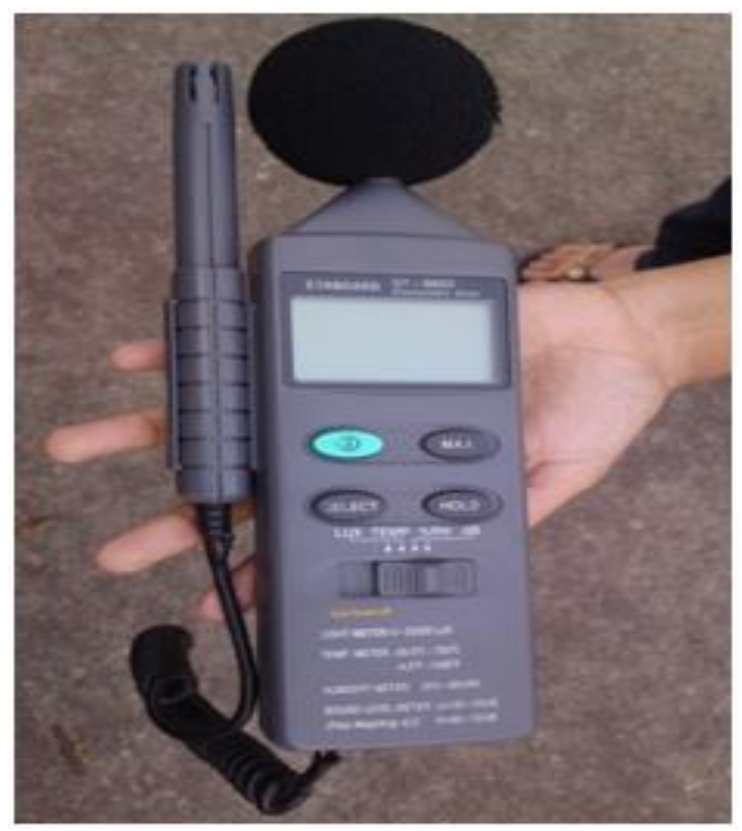

Fig-1: Sound Level Meter IES 61672-2003

\subsection{Material Testing}

The materials used in casting concrete sound barrier such as Cement, Fine aggregate (sand), Coarse aggregate, Water, rubber are tested as per IS standard. The tests carried out on cement were Standard consistency test, setting time test, fineness of cement by 90 microns sieve, specific gravity, and compressive strength.

The fine aggregate used in the construction of concrete barriers which was taken from CAUVERY river bed at TIRUMAKUDAL near T. NARSIPURA was tested for specific gravity and gradation. This river sand was totally free from all impurity and organic matters which confirms from IS: 383.

The coarse aggregate used in the concrete barriers were collected from CHINKURULLI quarry, which was well graded and angular in shape that confirms to IS: 2386, partI1963. Various tests conducted on coarse aggregate are specific gravity test, water absorption of coarse aggregate, impact test, crushing value test.

The rubber used in research work was obtained from the rebuilt tire factory by buffering of recycled tires and the tests conducted on rubber were specific gravity and Sieve analysis.

The results were compared with JK tyres project report to confirm the quality of rubber.

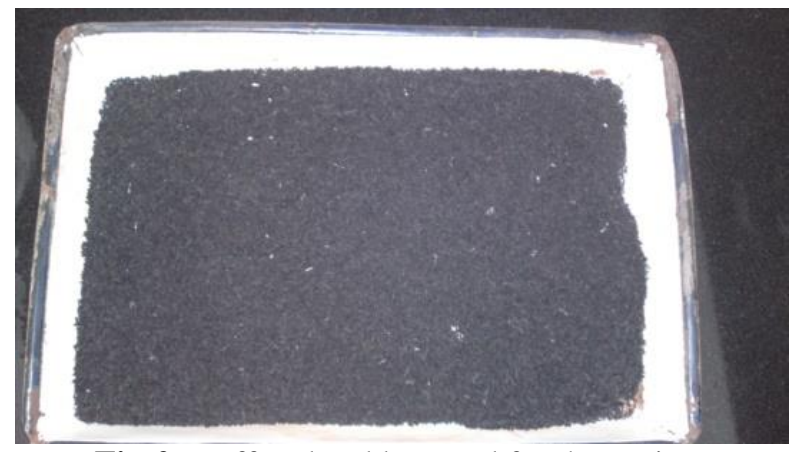

Fig-2: Buffered Rubber used for the project

\subsection{Method of Casting}

Tire rubber obtained from buffering of worn out tires produced in local tire rebuilt factory were used as admixture in concrete to improve sound absorbing property. According to IS Standards, the fine aggregate and coarse aggregate were weighed as calculated for specific proportion by passing through $4.75 \mathrm{~mm}$ and $20 \mathrm{~mm}$ IS sieve respectively and cement used was 53 grade.

Concrete mix was prepared in 1:1.5:3 proportion by using cement, sand and coarse aggregate with water/cement ratio of 0.55 . The fine aggregate was replaced by rubber varying in different percentage $10 \%, 15 \%, 20 \%, 25 \%, 30 \%, 35 \%$, $40 \%, 45 \%$, and $50 \%$. The mixture was mixed thoroughly to get consistent concrete paste; the time of mixing maintained was less than 3 to 4 minutes to obtain uniform color. Then the mixture was filled into the wooden panels of size $50 \times 60 \times 5 \mathrm{~cm}$ in 3 layers, each layer tamping with 25 stokes. Same mixture was subjected to slump test and compressive test to check the consistency of mix and its compressive strength.

The panels which were casted and cubes were cured thoroughly for 28 days. The compressive strength of cubes was tested for 7 days and 28 days. Then the panels were tested to check sound absorption capacity.

\subsection{Method of Testing Absorption Capacity}

The sound absorption capacity was checked using a wooden box of nearly $4 \mathrm{~m}$ length as shown in Fig-3 was placed on a $1.2 \mathrm{~m}$ height table in the laboratory. The sound level instrument is placed inside the box at the bottom nearly 3.5 $\mathrm{m}$ away from the noise producer (speaker), and the music was produced from the audio speakers for duration $3.7 \mathrm{~min}$ of uniform frequency. The barrier was placed in between audio speaker and sound level meter and the wooden box was maintained air tight. Then the audio speaker was played and the reading shown in the SOUND LEVEL METER was noted down. The same procedure was followed to measure noise absorption capacity for different trial mixes of the concrete barriers. 


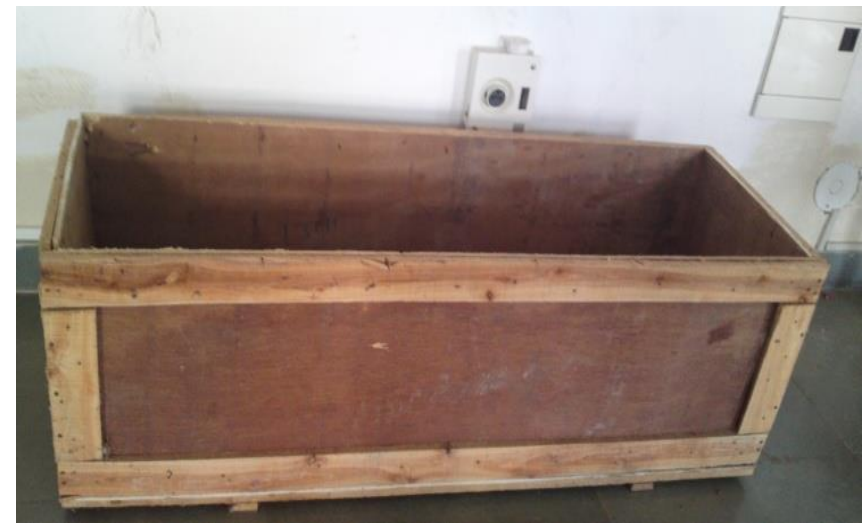

Fig- 3: Wooden box

\section{RESULT AND DISCUSSIONS}

\subsection{Traffic Survey}

\subsubsection{Traffic Density}

The peak traffic density was observed from 9.00 to $11.00 \mathrm{am}, 1.00$ to $3.00 \mathrm{pm}$ and 5.00 to $6.00 \mathrm{pm}$ near JSS hospital road in Agarahara, Narayanshastri Road near Sadvidya School and court road on 22 (Saturday), 23 (Sunday) and 03(Monday), May, 2010 respectively. In most of the study location during peak hour two wheelers and autos were highest in number. The study locations selected were based on observations that the traffic density was more and the buildings were constructed nearby road. Whereas the buildings of hospitals, schools and colleges should be $100 \mathrm{~m}$ away from the roadway hence, the barriers can be installed as a compound wall to decrease the noise level due to traffic. The Tables 3.1 through 3.3 shows the traffic density variations at selected study locations for varied time.

Location 1: JSS hospital road in Agarahara

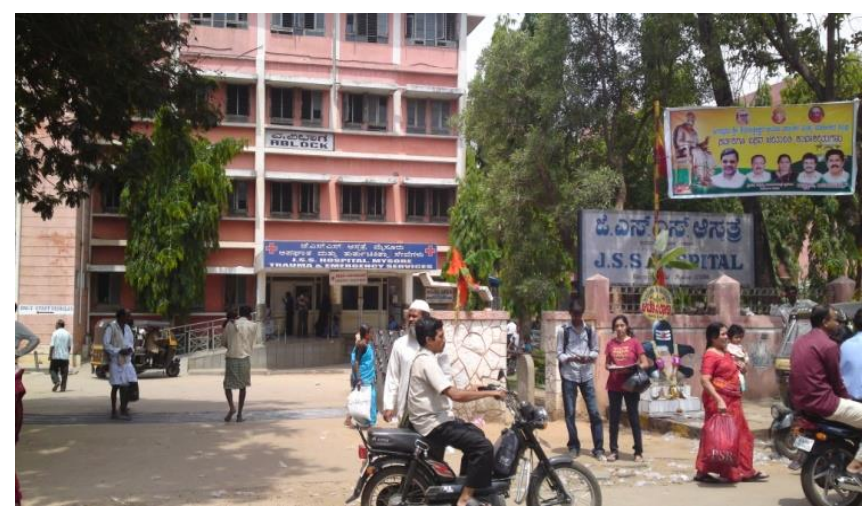

Fig- 4: Traffic survey at JSS hospital road in Agarahara

Table- 3.1: Traffic Density of Ramanuja Road near JSS Hospital from 9:00 am-7:00 pm

\begin{tabular}{|l|l|l|l|}
\hline $\begin{array}{l}\text { Category of } \\
\text { vehicles }\end{array}$ & $\begin{array}{l}\text { 9.00- } \\
11.00 a m\end{array}$ & $\begin{array}{l}\text { 1.00- } \\
\mathbf{3 . 0 0 p m}\end{array}$ & $\begin{array}{l}\mathbf{5 . 0 0 -} \\
\mathbf{7 . 0 0} \mathbf{p m}\end{array}$ \\
\hline Two Wheeler & 3296 & 2371 & 3178 \\
\hline Car & 652 & 513 & 829 \\
\hline Auto & 924 & 677 & 1140 \\
\hline Buses & 49 & 27 & 33 \\
\hline
\end{tabular}

Location 2: Narayanshastri road near Sadvidya School

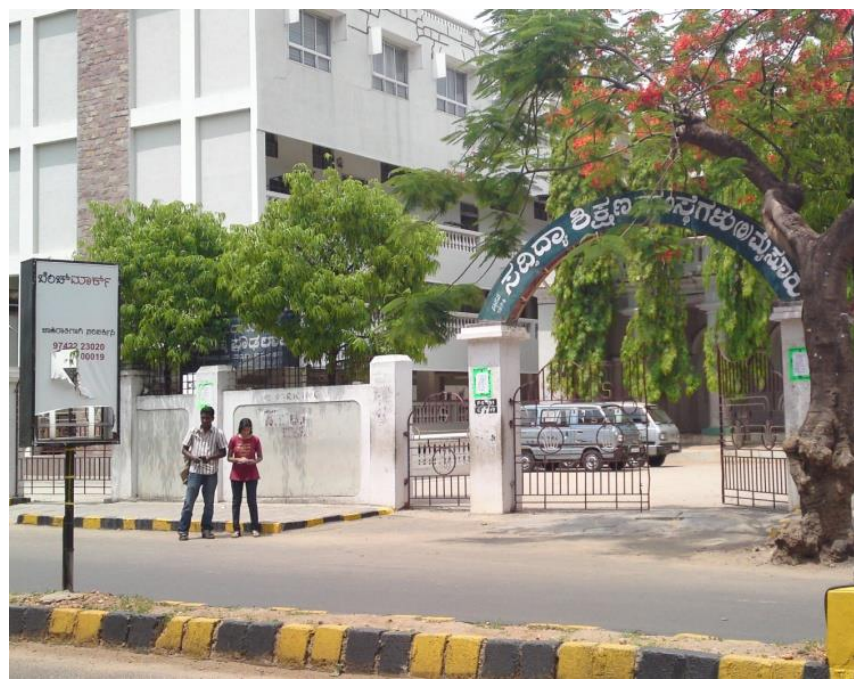

Fig- 5: Traffic Survey atNarayanshastri road near Sadvidya School

Table- 3.2: Traffic Density of Narayanshastri Road near Sadvidya School from 9:00 am-7:00 pm.

\begin{tabular}{|l|l|l|l|}
\hline $\begin{array}{l}\text { Category of } \\
\text { vehicles }\end{array}$ & $\begin{array}{l}\text { 9.00- } \\
\mathbf{1 1 . 0 0 a m}\end{array}$ & $\begin{array}{l}\mathbf{1 . 0 0 -} \\
\mathbf{3 . 0 0 p m}\end{array}$ & $\begin{array}{l}\mathbf{5 . 0 0 -} \\
\mathbf{7 . 0 0 p m}\end{array}$ \\
\hline Two Wheeler & 3146 & 2027 & 3091 \\
\hline Car & 1082 & 526 & 817 \\
\hline Auto & 966 & 773 & 1176 \\
\hline Buses & 52 & 29 & 34 \\
\hline
\end{tabular}

Location-3: Court road

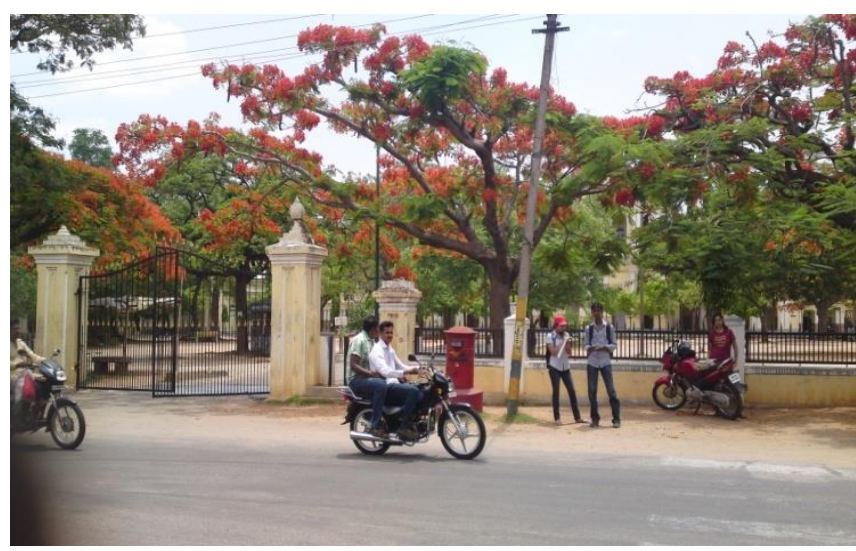

Fig-6: Traffic Survey at court road

Table- 3.3: Traffic Density of Court Road from 9:00 am11:00 am.

\begin{tabular}{|l|l|l|l|}
\hline $\begin{array}{l}\text { Category of } \\
\text { vehicles }\end{array}$ & $\begin{array}{l}\text { 9.00- } \\
\mathbf{1 1 . 0 0 a m}\end{array}$ & $\begin{array}{l}\mathbf{1 . 0 0 -} \\
\mathbf{3 . 0 0 p m}\end{array}$ & $\begin{array}{l}\mathbf{5 . 0 0 -} \\
\mathbf{7 . 0 0} \mathbf{p m}\end{array}$ \\
\hline Two Wheeler & 2668 & 1836 & 3025 \\
\hline Car & 640 & 685 & 688 \\
\hline Auto & 876 & 778 & 777 \\
\hline Buses & 5 & 8 & 5 \\
\hline
\end{tabular}




\subsubsection{Sound Pressure Level}

Traffic survey was conducted during peak time duration of 9.00 to $11.00 \mathrm{am}, 1.00$ to $3.00 \mathrm{pm}$ and 5.00 to $700 \mathrm{pm}$ at each location. It was observed that the sound pressure level were maximum of about $107 \mathrm{~dB}$ and $93.5 \mathrm{~dB}$ near entrance gate of JSS HOSPITAL, RAMANUJA road at 10.00 am and $1.40 \mathrm{pm}$ respectively. Further, peak sound pressure level of $100.1 \mathrm{~dB}$ was observed near the court road at $5.20 \mathrm{pm}$.

\subsection{Sound Absorption Test}

The concrete panel which was casted by replacing fine aggregate by rubber in varying percentage was tested to check its sound absorption capacity. Fig-7 reveals that the Sound absorption capacity of concrete panel increases as percentage of rubber increased.

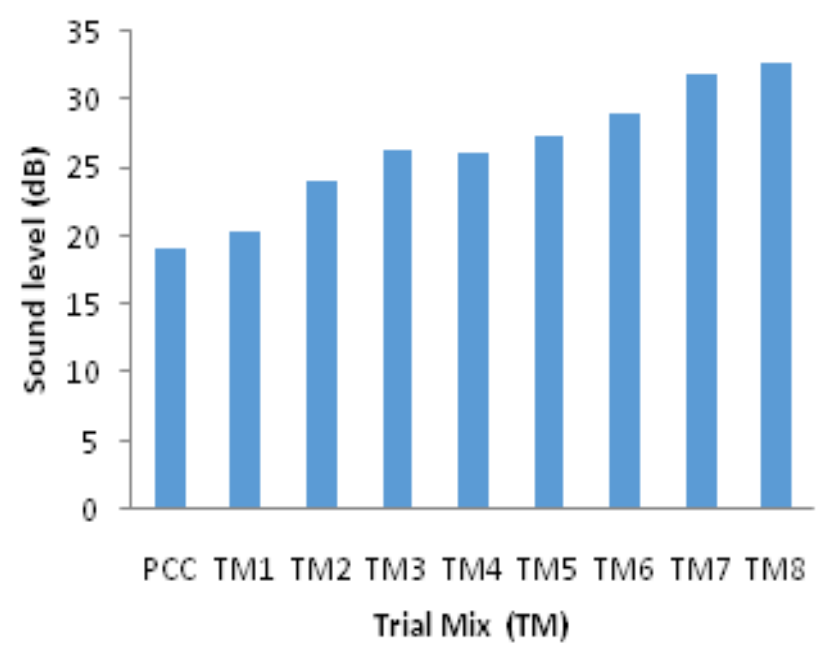

Fig- 7: Sound absorption capacity of panels

The concrete panel casted for different percentage of rubber replacement is also tested to check its compressive strength at the end of 7 days and 28 days. Fig- 8 shows that, the compressive strength decreases as the percentage of rubber increases when replaced with fine aggregate at 7 days and 28 days.

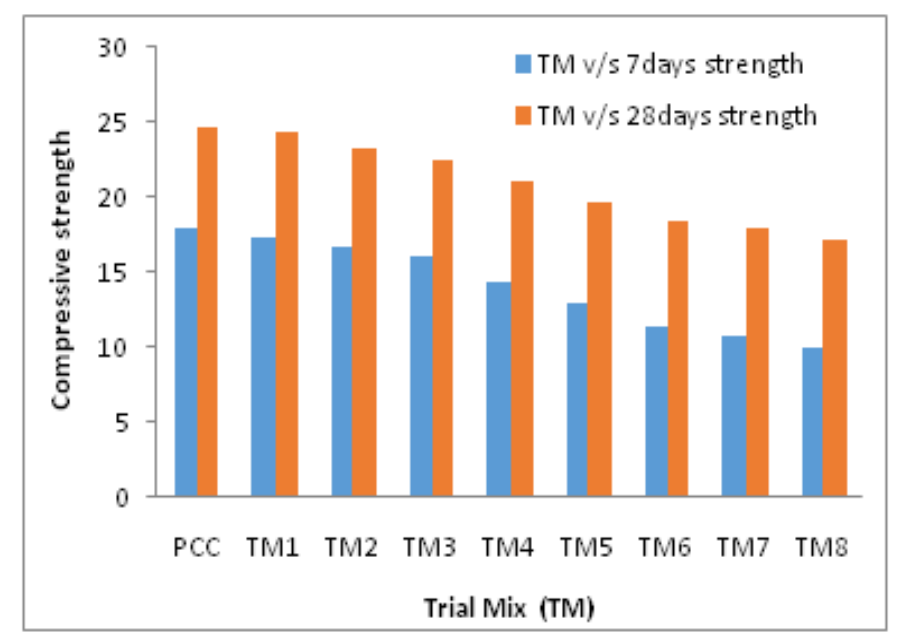

Fig- 8: Trial mix V/S Compressive strength in $\mathrm{N} / \mathrm{mm}^{2}$ for 7 days and 28 days
Where,

TM1 - fine aggregate replaced by $10 \%$ rubber TM2- fine aggregate replaced by $20 \%$ rubber TM3- fine aggregate replaced by $25 \%$ rubber TM4- fine aggregate replaced by $30 \%$ rubber TM5- fine aggregate replaced by $35 \%$ rubber TM6- fine aggregate replaced by $40 \%$ rubber TM7- fine aggregate replaced by $45 \%$ rubber TM8- fine aggregate replaced by $50 \%$ rubber PCC- plain cement concrete

\section{CONCLUSION}

The study locations selected based on its importance revealed the traffic density was peak from 9.00 to $11.00 \mathrm{am}$, 1.00 to $3.00 \mathrm{pm}$ and 5.00 to $7.00 \mathrm{pm}$. It was also observed that two wheelers and autos were highest in number. The sound pressure level were maximum of about $107 \mathrm{~dB}$ and 93.5 dB near entrance gate of JSS HOSPITAL, RAMANUJA road at 10.00 am and $1.40 \mathrm{pm}$ respectively and $100.1 \mathrm{~dB}$ near the court road at $5.20 \mathrm{pm}$.

The concrete panel casted for different percentage of rubber by replacement of fine aggregates was tested to check its sound absorption capacity. From the test results it can be observed that Sound absorption capacity of concrete panel increases as percentage of rubber increased. Whereas the compressive strength of concrete panels decreases as the percentage of rubber increases when replaced with fine aggregate at 7 days and 28 days.

In this work the mix proportion considered was $1: 1.5: 3$ with water cement ratio 0.55 for strength of M20. From the test results obtained it can be concluded that the rubber can be replaced with fine aggregate up to $35 \%$ for effective sound absorption of $27.5 \mathrm{~dB}$ by maintaining the compressive strength up to $19.6 \mathrm{~N} / \mathrm{mm}^{2}$

\section{ACKNOWLEDGEMENT}

I sincerely thank Vinay Kumar B. M. and Late. Suhas N for their contribution in the project workand also I wish to record my gratitude to the entire team with whom I interacted.

\section{REFERENCES}

[1] MalekJedidi, Ali Boulila, Omrane Benjeddou, Chokri Soussi (2014), "Crumb Rubber Effect on Acoustic Properties of Self- Consolidating Concrete", Int. J. of Thermal \& Environmental Engineering, Vol. 8, No. 2(2014), Pg. 69-76.

[2] Niall Holmes, Alex Browne, Christopher Montague(2014), “Acoustic Properties of Concrete Panels with Crumb Rubber As a Fine Aggregate Replacement", Construction and Building Materials, Vol.73,pp.195-204

[3] G.R Watts and R E Stait (2008), "Characteristics of Vehicles Producing Excessive Noise and Ground Borne Vibration- Phase I", TRL Report PPR202. TRL, Crowthome, UK. 
[4] F.Asdrubali, F. D'Alessandro and S. Schiavoni (2008) "Sound Absorbing Properties of materials made of rubber crumbs", Perugia, Italy

[5] Narendra Singh, S. C. Davar (2004) "Noise PollutionSources, Effects and Control”, J.Hum. E.coli. 16(3): 181-187.

[6] Recommended guide line for concrete mix design, IS 10262-1983(reaffirmed 2004), bureau of Indian standards New Delhi.

[7] Deutche(2003), "Noise cities make them dumb", Business Line, Presse- Agentur

[8] "Control of Body Noise from Commercial Vehicles Guide to Best Practice" (2000), Department of the Environment, Transport and the Regions, London, UK

[9] Indian standard code of practice for "Plain \& reinforced concrete code of practice", IS 4562000(fourth revision), bureau of Indian standards New Delhi.

[10] Indian standard code of practice for "methods of tests for strength of concrete", IS 516-1959(reaffirmed 1999), bureau of Indian standards New Delhi.

[11] Z.Li, ${ }^{* F . L i}$, ${ }^{*}$ J.S.L.Li (1999), "Properties of Concrete incorporating rubber tyre particles", Magazine of concrete Research, Pg. 297-304

[12] Specification for coarse and fine aggregates from material sources for concrete (second revision), IS 383-1970, bureau of Indian standards New Delhi.

[13] Touting H.A. (1996), "The use of rubber tyre particles in concrete to replace mineral aggregates in Cement and Concrete Composites", Vol. 18, Page no. 135-139

[14] Rao, P.R (1995), "Noise Pollution and Control, Encyclopedia of Environmental Pollution and Control", Environ media Publications, Vol.-2

[15] Harris, C. M. (Ed.) (1991) Handbook of acoustical measurements and noise control, $3^{\text {rd }}$ Edition, New York, McGraw-Hill, Inc

[16] Indian standard specification for 53 grade ordinary Portland cement, IS 12269, and bureau of Indian standards New Delhi.

[17] Rolling Noise and Vehicle Noise, TRRL Laboratory Report 652, TRL Wokingham.

[18] Scrap Tire and Rubber Recycling Terminology Booklet developed by the ITRA Tire and Rubber Recycling Advisory Council (TRRAC)

\section{Internet Addresses}

[19] http://www.google.com

[20] http://www.itra.com/corporate/recycling/trrac.htm

[21] http://www.rapra.net

[22] http://usrubber.com

[23] http://www.wekipedia.com

\section{BIOGRAPHIES}

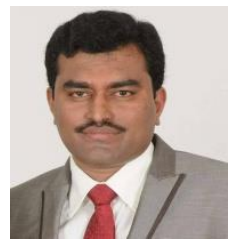

Dr. NAVEEN G.M. completed his B.E in Civil Engineering in UBDT, Davangere and M. Tech (Structural Engineering) from MCE, Hassan. He obtained his Ph.D in National Institute of Engineering, Mysore. Working as Asst. Professor, Department of Civil Engineering, Government Engineering College, Chamarajanagara, Karnataka, India

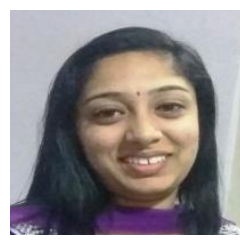

Ms. ICHITHA M. K. completed her B.E in Civil Engineering in Vidya Vikas Institute of Engineering and M. Tech (Hydraulics) from National Institute of Engineering, Mysore. Working as Asst. Professor in Department of Civil Engineering at Vidyavardhaka College of Engineering, Karnataka, India

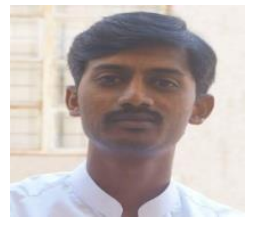

Mr. RAVI KIRAN L. completed his B.E in Civil Engineering in Vidya Vikas Institute of Engineering and $\mathrm{M}$. Tech (Marine Structures) from National Institute of Technology Karnataka, Suratkal. Working as Asst. Professor in Department of Civil Engineering at Sambhram Institute of Technology, Karnataka, India

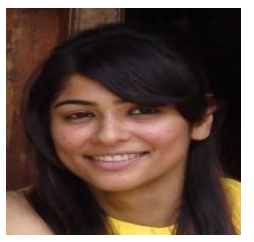

AYUSHI GOWTHAMJAIN, Project Associate, Department of Civil Engineering, Vidya Vikas Institute of Engineering and Technology, Karnataka, India 